\title{
Thermal-induced Residual Stresses and Distortions in Friction Stir Welds - A Literature Review
}

\author{
Mohamed H. El-Moayed*, Ahmed Y. Shash*,**, Mahmoud Abd Rabou*,***, \\ and Mahmoud G. El-Sherbiny* \\ *Mechanical Design and Production Department, Faculty of Engineering, Cairo University, Giza, 12613, Egypt \\ **Faculty of Engineering and Materials Science, German University in Cairo, New Cairo, 11835, Egypt \\ ***Faculty of Engineering, Zewail City of Science and Technology, Giza, 11341, Egypt
}

†Corresponding author: ahmed.shash@cu.edu.eg, ahmed.shash@guc.edu.eg

(Received March 11, 2021; Revised April 28, 2021; Accepted June 3, 2021)

\begin{abstract}
Friction Stir Welding (FSW) is a solid-state welding technique that uses the heat generated from friction to assemble a wide variety of materials. Irrespective of having a lower heat input as compared to conventional welding techniques, friction stir welds are still prone to significant thermal-induced stresses and distortions owing to the uneven heating and cooling cycles that a weld goes through. Surprisingly, not several reviews have addressed both the residual stresses and distortions of friction stir welds despite their crucial impact on the weld performance. Therefore, the current paper reviews their development, their correlation with process parameters, and ways to reduce them. Moreover, it explains the current status of process modeling and research gaps in the area of interest.
\end{abstract}

Key Words: Friction stir welding, Residual stresses, Distortion, Numerical modeling, Review

\section{Introduction}

Uneven heating and cooling cycles can leave a welded joint susceptible to significant residual stresses. Those stresses switch from tension to compression along the transverse direction, which, in some cases, can cause unwanted irregularities in the welded component. Dealing with the resulting irregularities is an expensive and time-consuming process. Unfortunately, owing to the welding process nature, the formation of residual stresses and their side-effects is inevitable and cannot be prevented. However, it can be controlled via process input parameters - the ones that affect the amount of heat input directly.

Residual stresses and distortions in friction stir welds, also known as the "residual states", have been investigated over the years, and many conclusions have been published. Nevertheless, the amount of research done in this area is still limited as compared to the amount of research devoted to investigating the effect of the process parameters on the mechanical properties. The same applies to the review articles publishing status over the past ten years. The authors herein are not trying to undermine the importance of analyzing process inputs-outputs correlations. They are, however, trying to bring a refreshing perspective to the field regarding this topic.

In 2011, Woo et al. ${ }^{1)}$ reviewed residual stress measurement by Neutron diffraction. They covered its theoretical background, practical issues, and applications. In 2015 , on the other hand, Hattel et al. ${ }^{2}$ reviewed the different modeling techniques of the residual stresses. Besides these two studies, the authors could not find any more reviews on welding-induced stresses. Moreover, no review to date has addressed thermal distortion in friction stir welds. Accordingly, the current paper is dedicated to covering the following topics:

- Residual states development,

- Effect of process parameters on residual states,

- Residual states mitigation techniques,

- Process modeling, and

- Research gaps. 


\section{Residual States Development}

Kumar et al. ${ }^{3)}$ explained in their book how residual stresses develop in the first place. Their demonstration was used as a reference in the current section. Fig. 1 shows an illustration of residual stress development in friction stir welds. In Fig. 1a, the green rectangle represents the portion of the base material to be welded, while the blue ones represent the portions that will not undergo any changes. The latter acts as rigid constraints to the former, preventing it from free expansion/ contraction.

During welding, the green region experiences a large amount of heat input for being in direct contact with the tool. As mentioned above, this region cannot expand freely due to its interaction with the adjacent material. Consequently, a compressive mechanical strain $\left(\mathrm{e}_{\mathrm{mec}}\right)$ is introduced at $T_{1}$, the peak welding temperature. Its value is equal to $\mathrm{C}$, which is the same value of the thermal strain $\left(e_{t h}\right)$ developed in the case of free thermal expansion at the same temperature (see Fig. 1b). If $\mathrm{C}$ is lower than the yield strain of the material, no dimensional changes will occur in the nugget zone (NZ). Otherwise, plastic deformation occurs, causing a permanent shape change.

Fig. 1c depicts the cooling stage during which the NZ would shrink if it were not for the rigid constraints. In other words, the adjacent material stretches the NZ from the position where it was allowed to shrink by strain $\mathrm{C}$ to the position where it does not shrink due to the presence of rigid constraints. Therefore, the NZ de-

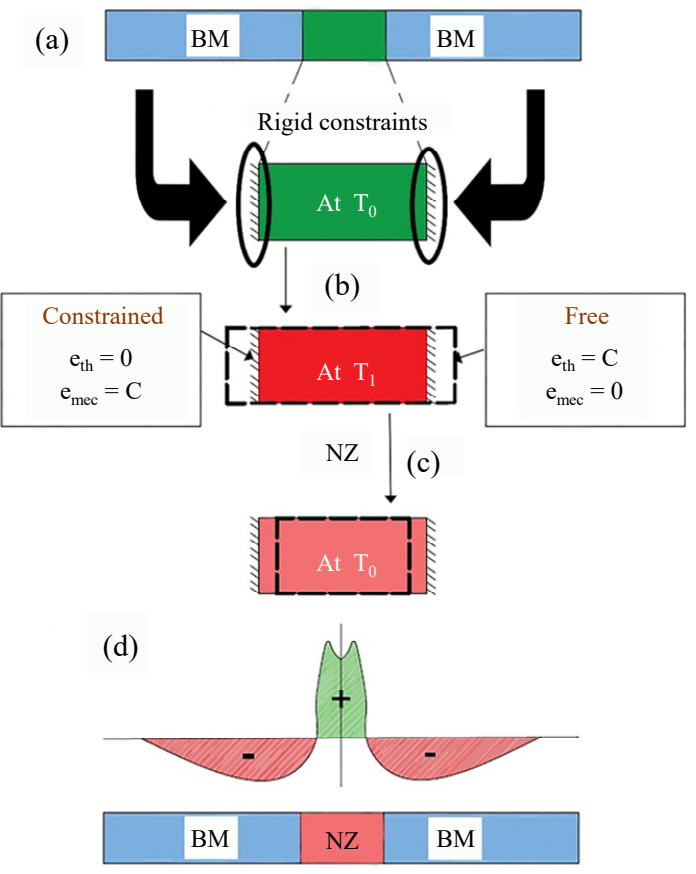

Fig. 1 Residual stress development illustration velops tensile stresses, reflecting its state. If the strain value outreaches the yield limit, lower tensile stresses are obtained due to stress relaxation triggered by permanent deformation.

In the absence of external constraints, the total sum of body forces must equal zero. Hence, the adjacent material forms compressive stresses to balance their tensile counterparts. Fig. 1d shows a typical residual stress distribution in the transverse direction. When compressive stresses exceed the critical buckling limit of the sheet, buckling distortion becomes inevitable upon de-clamping.

\section{Effect of Process Parameters on Residual States}

Residual properties are highly affected by the process parameters, especially the ones affecting the amount of heat input directly. So, it is no surprise that researchers have been investigating the effects of primary process parameters for the past few years. Parameters like rotational and traverse speeds are the most widely investigated ones, as proven in the next paragraphs.

He et al. ${ }^{4)}$ investigated the effect of rotational speed on longitudinal tensile residual stress in thick AA6061 friction stir welds. Their results showed that residual stress slightly increased with increasing the rotational speed, which was the opposite of what Tutum and Hattel ${ }^{5}$ reported. This increase was attributed to the high temperatures associated with high rotational speeds. Also, all stress distributions were double-peaked, shaped like an "M." The same observation was made back in 2003 by Peel et al. ${ }^{6}$, who studied the effect of traverse speed on residual stresses in AA5083 welds. Fig. 2 demonstrates the M-shaped residual stress profiles extracted from ${ }^{4}$.

Meanwhile, Peel et al. ${ }^{6}$ reported a positive correlation between longitudinal tensile residual stress and traverse speed. Feng et al. ${ }^{7}$, Tutum and $\mathrm{Hattel}^{5)}$, and Farajkhah and $\mathrm{Liu}^{8)}$ published an equivalent conclusion in their studies. They all agree that large heat input associated with low traverse speeds results in a more uniform thermal gradient along the transverse direction, causing a

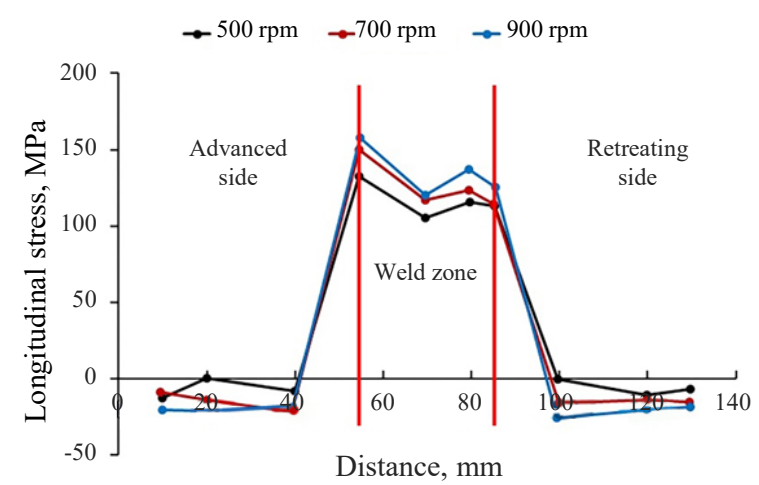

Fig. 2 Longitudinal residual stress distributions 


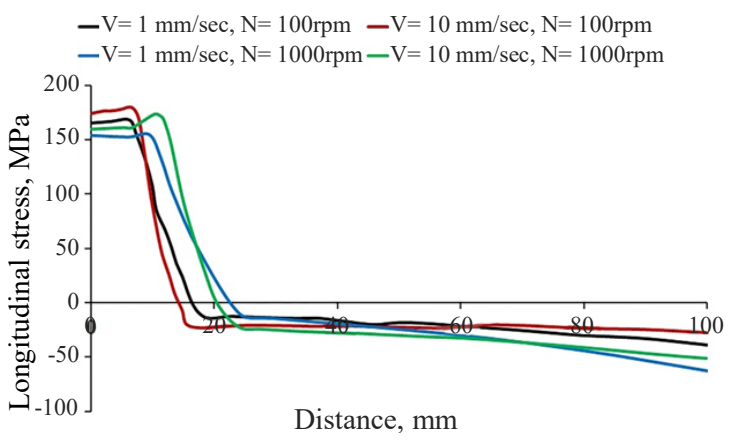

Fig. 3 Residual stress at different operating conditions

lower thermal contraction mismatch between the HAZ and adjacent material during cooling. Hence, reduced tensile residual stresses are obtained at low speeds and vice versa. Fig. 3 highlights the relationship between longitudinal residual stress and operating speeds.

While several authors claim that increasing the traverse speed increases the longitudinal tensile residual stress, others claim the opposite. Buffa et al. ${ }^{9)}$ and Camilleri et al. ${ }^{10)}$ mentioned in their studies that the correlation did not have to be always positive. However, no detailed explanation was provided by both research groups. Their statement should be taken with caution as not many publications reported such an observation.

The above-mentioned studies were mainly focused on longitudinal tensile residual stress in friction stir welds. Regarding out-of-plane distortion, not only is it influenced by processing speeds, but also sheet dimensions. Shi et al. ${ }^{11)}$ explored the effects of rotational speed, traverse speed, and sheet length on the geometric imperfection of AA6013 panels. Their experiments showed that increasing the rotational speed and sheet length could increase the distortion. Meanwhile, traverse speed did not show any significance whatsoever. Likewise, Zhang et al. ${ }^{12)}$ conducted a computational investigation of the size effects on AA6061 residual states. They concluded that sheet width had more control over distortion than the length, which was similar to what Costa et al. ${ }^{13)}$ published recently.

According to most distortion-related studies ${ }^{11-15)}$, friction stir welded sheets exhibit an "anti-saddle" pattern after de-clamping. In other words, they become concave in the transverse direction and convex in the longitudinal direction ${ }^{14)}$. Shi et al. ${ }^{11)}$ attributed the reversed saddle profile to the extension difference between the top and bottom sheet layers. During welding, the top layer is extruded by the tool in the welding direction, unlike the bottom layer, which is in almost rigid contact with the backing plate and cannot experience such interaction. Fig. 4 demonstrates the typical distortion shape after the FSW process.

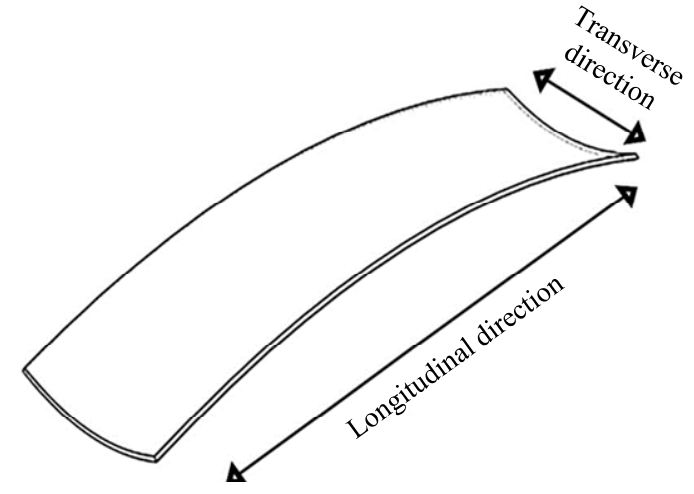

Fig. 4 Typical distortion shape of friction-stir welds

\section{Residual States Mitigation Techniques}

The formation of residual properties cannot be prevented but can be controlled by process input parameters to a certain limit. Beyond this limit, the residuals cannot be reduced further without the need for secondary thermal/mechanical loads. Hattel et al. ${ }^{2)}$ listed in their review four reduction techniques that were proposed by other researchers over time. The techniques are:

1. Thermal Tensioning,

2. Mechanical Tensioning,

3. Surface Treatment, and

4. Post-Weld Direct Rolling

\subsection{Thermal Tensioning}

The general idea of "Thermal Tensioning" is to stretch the weld zone before or during welding by imposing a preset temperature gradient ${ }^{16,17)}$. This thermal difference should allow for more expansion of the weld zone, thereby reducing its plasticity, which is the source of residual stresses and distortions ${ }^{18}$. The technique can be implemented statically or dynamically. The former is referred to as "Steady-State Thermal Tensioning, STT," while the latter is known as "Transient Thermal Tensioning, TTT." Fig. 5 displays the difference between
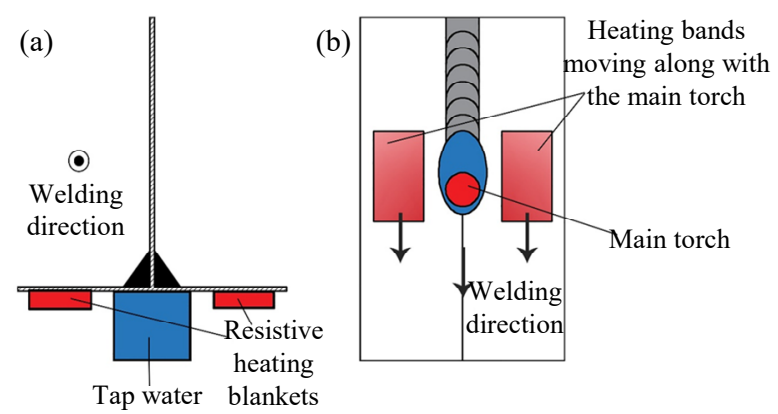

Fig. 5 Thermal tensioning technique, (a) Steady-State Thermal Tensioning (STT), (b) Transient Thermal Tensioning (TTT) 
STT and TTT.

STT requires a combination of cooling and heating before and during welding. According to Michaleris and Sun ${ }^{16)}$, STT with elastic pre-bending could minimize buckling and angular distortions of AH36 steel panels. The downside of STT is the cost of the apparatus, making it impractical for industrial applications ${ }^{2}$. TTT, on the other hand, does not have this limitation. In TTT, two moving heat sources are applied to each side of the main torch during welding only, which cuts the cooling equipment costs. Despite its cost-effectiveness, TTT is a complex optimization problem, as presented by Michaleris et al. ${ }^{17)}$, that involves intense computational runs to determine the optimum size and intensity of heating bands as well as their distances from the main torch. It is worth mentioning that little to no work has addressed STT and TTT applicability to the FSW process.

\subsection{Mechanical Tensioning}

The general idea of "Mechanical Tensioning, MT" is very similar to that of "Thermal Tensioning." However, instead of stretching the part thermally, it is clamped from one end and pulled mechanically from the opposite side. The mechanical pull must remain uniform before and during welding. Fig. 6 shows a schematic representation of the technique. According to Price et al. ${ }^{19)}$, MT was successful in flattening the residual stress profile and, hence, eliminating buckling distortion of AA2024 sheets. Nevertheless, like STT, MT is not widely used due to the expense of its equipment ${ }^{18)}$.

\subsection{Surface Treatment}

The surface treatment takes on many forms. Some of which are shot, laser, and needle peening. They all share the concept of introducing single or multiple layers of compressive residual stress near the part's surface by impact. The source and mechanism of impact are what differentiate one form from another. Fig. 7 highlights the difference between the above-mentioned forms. The compressive pressure wave in shot and needle peening is formed by mechanical impact. On the

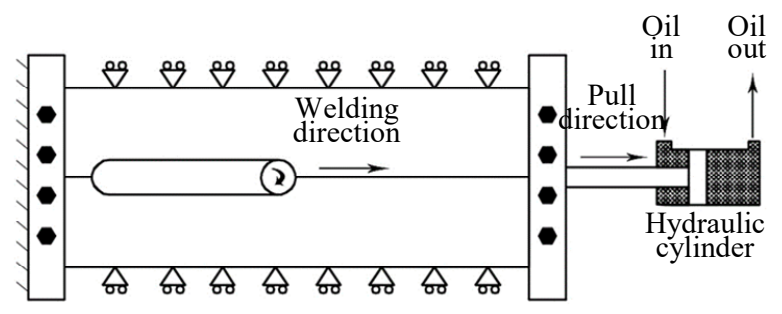

Fig. 6 Mechanical tensioning process
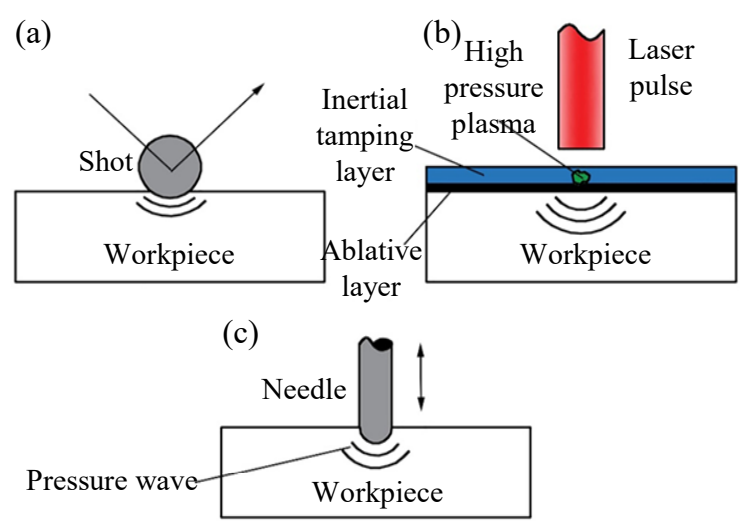

Fig. 7 Surface treatment processes, (a) Shot peening, (b) Laser peening, (c) Needle peening.

other hand, in laser peening, the pressure is formed by the rapidly expanding plasma trapped between the workpiece and the tamping layer ${ }^{20)}$.

Hatamleh et al. ${ }^{21)}$ highlighted the ability of laser peening to enhance the mechanical properties of AA7075 friction stir welds. Moreover, they stated that shot peening had minimal effect on the properties compared to its laser counterpart. For AA2024 sheets, Larose et al. ${ }^{22)}$ managed to reduce the distortion with needle peening by $37 \%$ and $82 \%$ in both transverse and longitudinal directions, respectively. With their study, they introduced needle peening as an effective mitigation technique.

\subsection{Post-Weld Direct Rolling}

As the name implies, Post-Weld Direct Rolling (PWDR) is a mitigation technique that takes place after the welding process is done. As shown in Fig. 8, a roller is pressed against the weld and moved in the longitudinal direction. When the weld is squeezed in the thickness direction, it elongates in the other two directions due to volume constancy. Furthermore, tensile residual stresses are relieved and become compressive. The magnitude of rolling-induced compressive stresses depends on the roller size and downward force. Based on the results from Altenkirch et al. ${ }^{23)}$ and Wen et al. ${ }^{24)}$, PWDR is a very enabling technology with great potential in the aerospace sector.

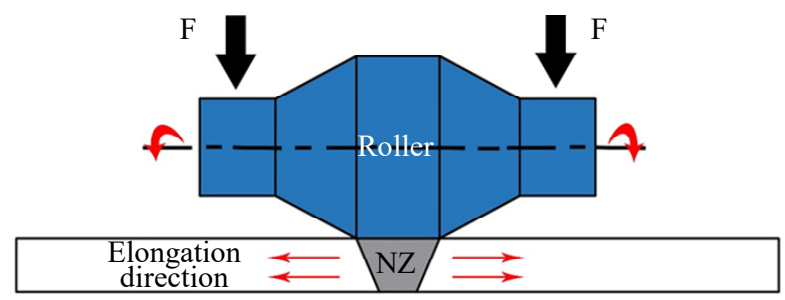

Fig. 8 Post-weld direct rolling 


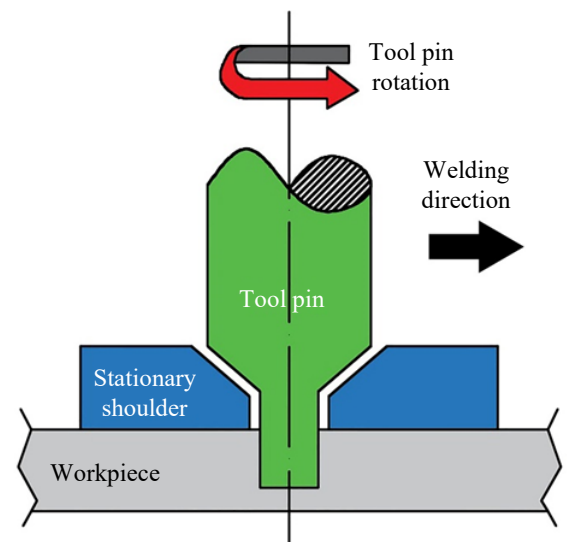

Fig. 9 Stationary shoulder friction stir welding

\subsection{Stationary Shoulder Friction Stir Welding}

Stationary Shoulder Friction Stir Welding (SSFSW) is a relatively new variant of the conventional FSW process.
Its tool consists of a pin that rotates independently of its shoulder (see Fig. 9). The external stationary shoulder absorbs a large portion of frictional heat, thereby reducing the peak welding temperature. Hence, a narrower NZ and tensile region are obtained. Recent studies $^{25-27)}$ reported promising results regarding the capability of SSFSW as an in-situation mitigation technique. As compared to other techniques, SSFSW does not require expensive apparatus, making it practical for both research and industrial applications.

\section{Residual States Modeling Status}

Finite Element Modeling (FEM) has always been a useful tool for analyzing different aspects of the FSW process, such as transient temperature fields, thermal-induced stress fields, and material flow patterns. The reason is that FEM can obtain instantaneous results and save research time and cost. Table 1 lists a few ex-

Table 1 Examples of FE models developed by different authors over the years

\begin{tabular}{|c|c|c|c|c|c|c|c|c|}
\hline \multirow{2}{*}{ Authors } & \multirow{2}{*}{ Year } & \multirow{2}{*}{ Form. } & \multirow{2}{*}{ Sym. } & \multicolumn{5}{|c|}{ Field output } \\
\hline & & & & Temp. & SS & Distort. & Mat. Flow & Met. \\
\hline Frigaard et al. $^{28)}$ & 2001 & - & No & $\square$ & & & & $\square$ \\
\hline Chao et al. ${ }^{29)}$ & 2003 & $\mathrm{~L}$ & Yes & $\square$ & & & & \\
\hline Chen and Kovacevic ${ }^{30)}$ & 2003 & L & Yes & $\square$ & $\square$ & & & \\
\hline Khandkar et al. $^{31)}$ & 2003 & $\mathrm{~L}$ & No & $\square$ & & & & \\
\hline Song and Kovacevic ${ }^{32)}$ & 2003 & $\mathrm{~L}$ & Yes & $\square$ & & & & \\
\hline Deng and $\mathrm{Xu}^{33)}$ & 2004 & ALE & No & $\square$ & & & $\square$ & \\
\hline Zhu and $\mathrm{Chao}^{34)}$ & 2004 & $\mathrm{~L}$ & Yes & $\square$ & $\square$ & & & \\
\hline Chao et al. $^{35)}$ & 2005 & CEL & No & $\square$ & & & $\square$ & \\
\hline Fratini and $\mathrm{Buffa}^{36)}$ & 2005 & ALE & No & & & & & $\square$ \\
\hline Schmidt and Hattel ${ }^{37)}$ & 2005 & ALE & No & $\square$ & & & $\square$ & \\
\hline Soundararajan et al. ${ }^{38)}$ & 2005 & $\mathrm{~L}$ & No & $\square$ & $\square$ & & & \\
\hline Heurtier et al. ${ }^{39)}$ & 2006 & - & No & $\square$ & & & $\square$ & $\square$ \\
\hline Khandkar et al. ${ }^{40)}$ & 2006 & $\mathrm{~L}$ & No & $\square$ & $\square$ & & & \\
\hline Uyyuru and Kailas ${ }^{41)}$ & 2006 & $\mathrm{~L}$ & No & $\square$ & $\square$ & & $\square$ & \\
\hline Feng et al. $^{7)}$ & 2007 & $\mathrm{~L}$ & Yes & $\square$ & $\square$ & & & $\square$ \\
\hline Murphy et al. $^{42)}$ & 2007 & $\mathrm{~L}$ & No & $\square$ & $\square$ & $\square$ & & \\
\hline Zhang et al. ${ }^{43)}$ & 2007 & ALE & No & $\square$ & & & $\square$ & \\
\hline Bastier et al. $^{44)}$ & 2008 & ALE & No & $\square$ & $\square$ & $\square$ & & $\square$ \\
\hline Schmidt and Hattel ${ }^{45)}$ & 2008 & CFD & No & $\square$ & & & & \\
\hline Qin and Michaleris ${ }^{46)}$ & 2009 & CEL & No & $\square$ & $\square$ & & & \\
\hline Assidi et al. $^{47)}$ & 2010 & ALE & No & $\square$ & & & & \\
\hline Prasanna et al. $^{48)}$ & 2010 & - & No & $\square$ & & & & \\
\hline Richards et $\mathrm{a}^{49)}$ & 2010 & $\mathrm{~L}$ & No & $\square$ & $\square$ & $\square$ & & \\
\hline Tutum and Hattel ${ }^{5)}$ & 2010 & $\mathrm{~L}$ & Yes & $\square$ & $\square$ & & & \\
\hline Wang et al. $^{50)}$ & 2010 & $\mathrm{~L}$ & No & $\square$ & $\square$ & & & \\
\hline
\end{tabular}


Table 1 (Cont.)

\begin{tabular}{|c|c|c|c|c|c|c|c|c|}
\hline \multirow{2}{*}{ Authors } & \multirow{2}{*}{ Year } & \multirow{2}{*}{ Form. } & \multirow{2}{*}{ Sym. } & \multicolumn{5}{|c|}{ Field output } \\
\hline & & & & Temp. & SS & Distort. & Mat. Flow & Met. \\
\hline Buffa et al. ${ }^{9)}$ & 2011 & $\mathrm{~L}$ & No & $\square$ & $\square$ & & & \\
\hline Jacquin et al. ${ }^{51)}$ & 2011 & CEL & No & $\square$ & & & $\square$ & \\
\hline Riahi and Nazari ${ }^{52)}$ & 2011 & $\mathrm{~L}$ & No & $\square$ & $\square$ & & & \\
\hline Yan et al. ${ }^{14)}$ & 2011 & L & No & $\square$ & $\square$ & $\square$ & & \\
\hline Aval et al. ${ }^{53)}$ & 2012 & ALE & No & $\square$ & $\square$ & & & \\
\hline McCune et al. ${ }^{15)}$ & 2012 & $\mathrm{~L}$ & No & $\square$ & $\square$ & $\square$ & & \\
\hline Al-Badour et al. $^{54)}$ & 2013 & CEL & No & & & & $\square$ & \\
\hline Mun and $\mathrm{Seo}^{55)}$ & 2013 & $\mathrm{~L}$ & Yes & $\square$ & $\square$ & $\square$ & & \\
\hline Sonne et al. $^{56)}$ & 2013 & $\mathrm{~L}$ & Yes & $\square$ & $\square$ & & & $\square$ \\
\hline Darvazi and Iranmanesh ${ }^{57)}$ & 2014 & $\mathrm{~L}$ & No & $\square$ & $\square$ & & & \\
\hline Shi et al. ${ }^{58)}$ & 2014 & CEL & No & $\square$ & & & $\square$ & \\
\hline Zhang et al. ${ }^{12)}$ & 2014 & $\mathrm{~L}$ & No & $\square$ & $\square$ & $\square$ & & \\
\hline Camilleri et al. ${ }^{10)}$ & 2015 & L & No & $\square$ & $\square$ & $\square$ & & \\
\hline Casavola et al. ${ }^{59)}$ & 2015 & $\mathrm{~L}$ & Yes & $\square$ & $\square$ & & & \\
\hline Shi et al. ${ }^{60)}$ & 2015 & CFD & No & $\square$ & & & $\square$ & \\
\hline Asadi et al. ${ }^{61)}$ & 2016 & - & No & $\square$ & & & & $\square$ \\
\hline Aziz et al. $^{62)}$ & 2016 & ALE & No & $\square$ & & & & \\
\hline Bachmann et al. ${ }^{63)}$ & 2017 & $\mathrm{~L}$ & Yes & $\square$ & $\square$ & & & $\square$ \\
\hline Dialami et al. ${ }^{64)}$ & 2017 & ALE & No & $\square$ & $\square$ & & & \\
\hline Farajkhah and $\mathrm{Liu}^{8)}$ & 2017 & $\mathrm{~L}$ & No & $\square$ & $\square$ & & & \\
\hline Hou et al. ${ }^{65)}$ & 2018 & CEL & No & $\square$ & $\square$ & & & \\
\hline $\mathrm{Yu}$ et al. ${ }^{66)}$ & 2018 & $\mathrm{~L}$ & No & $\square$ & $\square$ & & & \\
\hline Costa et al. ${ }^{13)}$ & 2019 & $\mathrm{~L}$ & Yes & $\square$ & $\square$ & $\square$ & & \\
\hline He et al. $^{25)}$ & 2019 & $\mathrm{~L}$ & No & $\square$ & $\square$ & $\square$ & & \\
\hline Salimi et al. $^{67)}$ & 2019 & CEL & No & $\square$ & $\square$ & & & \\
\hline Zhang et al. $^{68)}$ & 2019 & $\mathrm{~L}$ & Yes & $\square$ & $\square$ & & & \\
\hline $\mathrm{Xu}$ et al. ${ }^{69)}$ & 2020 & $\mathrm{~L}$ & No & $\square$ & $\square$ & & & \\
\hline $\mathrm{Yu}$ et al. $^{70)}$ & 2020 & $\mathrm{~L}$ & No & $\square$ & $\square$ & $\square$ & & \\
\hline
\end{tabular}

amples from the literature.

By analyzing the data in Table 1, it can be concluded that transient heat transfer is the most numerically investigated process aspect. The same applies to active/residual stress analysis. On the other hand, the total number of numerical studies dedicated to out-of-plane distortion, material flow, and metallurgical properties, such as hardness and grain size, is still deficient, as shown in Fig. 10. The degree of complexity and computational cost are the main constraints of these kinds of studies. It can also be concluded that only $23 \%$ of researchers have considered symmetry in their publications regardless of the asymmetric nature of the FSW process. According to McCune et al. ${ }^{15)}$, the asym-

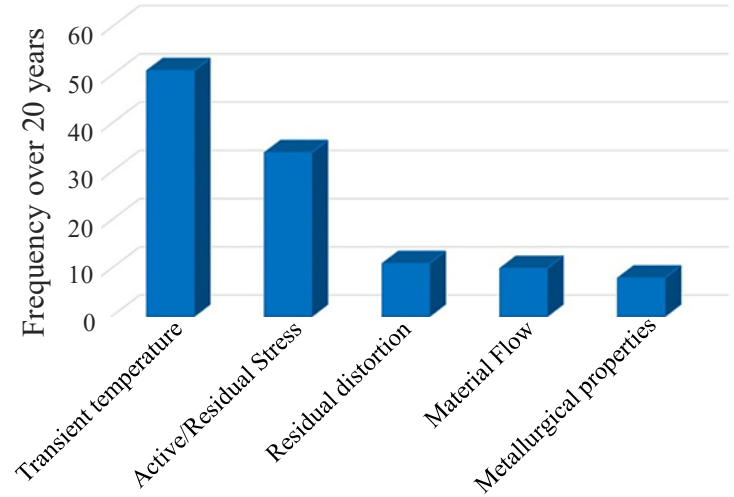

Field output

Fig. 10 Frequency analysis of the numerical studies conducted within the past 20 years 
metrical variations caused by the tool torque have an insignificant effect on heat and stress distributions.

\section{Conclusions}

The current literature review was mainly focused on welding-induced residual stress and distortion development, controlling parameters, and mitigation techniques. It also reflected on the present status of the FSW process modeling. In light of the gathered information, five literature gaps were discovered. First, little to no work has addressed the effects of tool geometry, tilt angle, and plunge depth on the residual states of friction stir welds. Second, no study to date has examined the statistical significance of process parameters plus their interactions in affecting welds' residual properties. Third, no study, to our knowledge, has discussed the applicability of thermal tensioning to the FSW process. Fourth, SSFSW is a promising mitigation technique that still requires a thorough investigation. Fifth, only a few numerical models have been developed to predict out-ofplane distortion, material flow patterns, and metallurgical properties of friction stir welds.

ORCID: Mbhamed H El-Mbayed: hittps://orcid.org/0000-0001-55541582 ORCID: Ahmed Y. Shash: https://orcid.org/0000-0002-8135-4761 ORCID: Mahmoud Abd Rabou: https://orcid.org/0000-0002-5020-3231 ORCID: El-Sherbiny: https://orcid.org/0000-0003-4562-6616

\section{References}

1. W. Woo, Z. Feng, X. L. Wang, and S. A. David, Neutron diffraction measurements of residual stresses in friction stir welding: A review, Sci. Technol. Weld. Join. 16 (2011) 23-32.

https://doi.org/10.1179/136217110X12731414739916

2. J. H. Hattel, M. R. Sonne, and C. C. Tutum, Modelling residual stresses in friction stir welding of $\mathrm{Al}$ alloys - a review of possibilities and future trends. Int. J. Adv. Manuf. Technol. 76 (2015) 1793-1805.

https://doi.org/10.1007/s00170-014-6394-2

3. N. Kumar, R. S. Mishra, and J. A. Baumann, Model for Understanding Residual Stress Development in Friction Stir Welded Structures. In: Residual Stresses in Friction Stir Welding, 1st edition Butterworth-Heinemann, (2013) 28-35.

4. J. He, Z. Ling, and H. Li, Effect of tool rotational speed on residual stress, microstructure, and tensile properties of friction stir welded 6061-T6 aluminum alloy thick plate, Int. J. Adv. Manuf. Technol. 84 (2016) 1953-1961. https://doi.org/10.1007/s00170-015-7859-7

5. C. C. Tutum and J. H. Hattel, Optimisation of process parameters in friction stir welding based on residual stress analysis: a feasibility study, Sci. Technol. Weld.
Join. 15 (2010) 369-377.

https://doi.org/10.1179/136217110x12707333260455

6. M. Peel, A. Steuwer, M. Preuss, and P. J. Withers, Microstructure, mechanical properties and residual stresses as a function of welding speed in aluminium AA5083 friction stir welds, Acta. Mater. 51 (2003) 4791-4801. https://doi.org/10.1016/S1359-6454(03)00319-7

7. Z. Feng, X. L. Wang, S. A. David, and P. S. Sklad, Modelling of residual stresses and property distributions in friction stir welds of aluminium alloy 6061-T6, Sci. Technol. Weld. Join. 12 (2007) 348-356. https://doi.org/10.1179/174329307X197610

8. V. Farajkhah and Y. Liu, Effect of clamping area and welding speed on the friction stir welding-induced residual stresses, Int. J. Adv. Manuf. Technol. 90 (2017) 339-348.

https://doi.org/10.1007/s00170-016-9393-7

9. G. Buffa, A. Ducato, and L. Fratini, Numerical procedure for residual stresses prediction in friction stir welding, Finite. Elem. Anal. Des. 47 (2011) 470-476. https://doi.org/10.1016/j.finel.2010.12.018

10. D. Camilleri, D. Micallef, and P. Mollicone, Thermal stresses and distortion developed in mild steel DH36 friction stir-welded plates: An experimental and numerical assessment, J. Therm. Stress. 38 (2015) 485508. https://doi.org/10.1080/01495739.2015.1015856

11. Q. Y. Shi, J. Silvanus, Y. Liu, and H. K. Li, Experimental study on distortion of Al-6013 plate after friction stir welding, Sci. Technol. Weld. Join. 13 (2008) 472-478. https://doi.org/10.1179/174329308x341924

12. Z. Zhang, Z. Zhang, and Zhang, Numerical investigations of size effects on residual states of friction stir weld, Proceeding of the Institution of Mechanical Engineers, Part B: J. Eng. Manuf. 228 (2014) 572-581. https://doi.org/10.1177/0954405413506191

13. M. I. Costa, C. Leitão, and D. M. Rodrigues, Parametric study of friction stir welding induced distortion in thin aluminium alloy plates: A coupled numerical and experimental analysis, Thin.Walled. Struct. 134 (2019) 268-276. https://doi.org/10.1016/j.tws.2018.10.027

14. D. Y. Yan, A. P. Wu, J. Silvanus, and Q. Y. Shi, Predicting residual distortion of aluminum alloy stiffened sheet after friction stir welding by numerical simulation, Mater. Des. 32 (2011) 2284-2291. https://doi.org/10.1016/j.matdes.2010.11.032

15. R. W. McCune, A. Murphy, M. Price, and J. Butterfield, The influence of friction stir welding process idealization on residual stress and distortion predictions for future airframe assembly simulations, J. Manuf. Sci. Eng. Trans. 134 (2012) 1-10. https://doi.org/10.1115/1.4006554

16. P. Michaleris and X. Sun, Finite element analysis of 
thermal tensioning techniques mitigating weld buckling distortion, Weld. J. 76 (1997) 451-s.

17. P. Michaleris, J. Dantzig, and D. Tortorelli, Minimization of welding residual stress and distortion in large structures, Weld. J. 78 (1999) 361-s

18. K. K. Tamma, Encyclopedia of Thermal Stresses, Springer Publishers (2013).

19. D. A. Price, S. W. Williams, A. Wescott, C. J Harrison A. Rezai, A. M. Peel, P. Staron, and M. Kocak, Steuwer, Distortion control in welding by mechanical tensioning, Sci. Technol. Weld. Join. 12 (2007) 620-633. https://doi.org/10.1179/174329307×213864

20. O. Hatamleh, The effects of laser peening and shot peening on mechanical properties in friction stir welded 7075-T7351 aluminum, J. Mater. Eng. Perform., 17 (2008) 688-694.

https://doi.org/10.1007/s11665-007-9163-7

21. O. Hatamleh, J. Lyons, and R. Forman, Laser and shot peening effects on fatigue crack growth in friction stir welded 7075-T7351 aluminum alloy joints, Int. J. Fatigue, 29 (2007) 421-434.

https://doi.org/10.1016/j.ijfatigue.2006.05.007

22. S. Larose, L. Dubourg, C. Perron, M. Jahazi, and P. Wanjara, Limitation of Distortion in Friction Stir Welded (FSW) Panels Using Needle Peening, Mater. Sci. Forum. 638-642 (2010) 1203-1208.

https://doi.org/10.4028/www.scientific.net/msf.638-642.1203

23. J. Altenkirch, A. Steuwer, P. J. Withers, S. W. Williams, M. Poad, and S. W. Wen, Residual stress engineering in friction stir welds by roller tensioning, Sci. Technol. Weld. Join. 14 (2009) 185-192. https://doi.org/10.1179/136217108x388624

24. S. W. Wen, P. A. Colegrove, S. W. Williams, S.A. Morgan, A. Wescott, and M. Poad, Rolling to control residual stress and distortion in friction stir welds, Sci. Technol. Weld. Join. 15 (2010) 440-447. https://doi.org/10.1179/136217110x12785889549787

25. W. He, M. Li, Q. Song, J. Liu, and W. Hu, Efficacy of External Stationary Shoulder for Controlling Residual Stress and Distortion in Friction Stir Welding, Trans. Indian Inst. Met. 72 (2019) 1349-1359. https://doi.org/10.1007/s12666-019-01630-2

26. W. He, J. Liu, W. Hu, G. Wang, and W. Chen, Controlling residual stress and distortion of friction stir welding joint by external stationary shoulder, High Temp. Mater. Process, 38 (2019) 662-671. https://doi.org/10.1515/htmp-2019-0005

27. B. Vicharapu, H. Liu, H. Fujii, K. Narasaki, N. Ma, and A. De, Probing residual stresses in stationary shoulder friction stir welding process. Int J Adv Manuf Technol, 106 (2020) 1573-1586. https://doi.org/10.1007/s00170-019-04570-9

28. Ø. Frigaard, Ø. Grong, and O. T. Midling, A process model for friction stir welding of age hardening aluminum alloys, Metall. Mater. Trans. A, 32 (2001) 1189-
1200.

https://doi.org/10.1007/s11661-001-0128-4

29. Y. J. Chao, X. Qi, and W. Tang, Heat transfer in friction stir welding - Experimental and numerical studies, J. Manuf. Sci. Eng. Trans. 125 (2003) 138-145. https://doi.org/10.1115/1.1537741

30. C. M. Chen and R. Kovacevic, Finite element modeling of friction stir welding - Thermal and thermomechanical analysis, Int. J. Mach. Tools Manuf. 43 (2003) 1319-1326. https://doi.org/10.1016/S0890-6955(03)00158-5

31. M. Z. H. Khandkar, J. A. Khan, and A. P. Reynolds, Prediction of temperature distribution and thermal history during friction stir welding: Input torque based model, Sci. Technol. Weld. Join. 8 (2003) 165-174. https://doi.org/10.1179/136217103225010943

32. M. Song and R. Kovacevic, Thermal modeling of friction stir welding in a moving coordinate system and its validation, Int. J. Mach. Tools Manuf. 43 (2003) 605615. https://doi.org/10.1016/S0890-6955(03)00022-1

33. X. Deng and S. Xu, Two-dimensional finite element simulation of material flow in the friction stir welding process, J, Manuf. Process, 6 (2004) 125-133. https://doi.org/10.1016/S1526-6125(04)70066-3

34. X. K. Zhu and Y. J. Chao, Numerical simulation of transient temperature and residual stresses in friction stir welding of 304L stainless steel, J. Mater. Process Technol. 146 (2004) 263-272. https://doi.org/10.1016/j.jmatprotec.2003.10.025

35. J. H. Cho, D. E. Boyce, and P. R. Dawson, Modeling strain hardening and texture evolution in friction stir welding of stainless steel, Mater. Sci. Eng. A, 398 (2005) 146-163. https://doi.org/10.1016/j.msea.2005.03.002

36. L. Fratini and G. Buffa, CDRX modelling in friction stir welding of aluminium alloys, Int. J. Mach. Tools Manuf. 45 (2005) 1188-1194. https://doi.org/10.1016/j.ijmachtools.2004.12.001

37. H. Schmidt and J. Hattel, A local model for the thermomechanical conditions in friction stir welding, Model Simul. Mater. Sci. Eng. 13 (2005) 77-93. https://doi.org/10.1088/0965-0393/13/1/006

38. V. Soundararajan, S. Zekovic, and R. Kovacevic, Thermomechanical model with adaptive boundary conditions for friction stir welding of Al 6061, Int. J. Mach. Tools Manuf. 45 (2005) 1577-1587. https://doi.org/10.1016/j.ijmachtools.2005.02.008

39. C. Desrayaud, S. Ringeval, S. Girard, and J. H. Driver, A novel high straining process for bulk materials - The development of a multipass forging system by compression along three axes, J. Mater. Process Technol. 172 (2006) 152-158.

https://doi.org/10.1016/j.jmatprotec.2005.09.015

40. M. Z. H. Khandkar, J. A. Khan, A. P. Reynolds, and 
M. A. Sutton, Predicting residual thermal stresses in friction stir welded metals, J. Mater. Process. Technol. 174 (2006) 195-203.

https://doi.org/10.1016/j.jmatprotec.2005.12.013

41. R. K. Uyyuru and S. V. Kallas, Numerical analysis of friction stir welding process, J, Mater, Eng, Perform, 15 (2006) 505-518.

https://doi.org/10.1361/105994906X136070

42. A. Murphy, W. McCune, D. Quinn, and M. Price, The characterisation of friction stir welding process effects on stiffened panel buckling performance, Thin-Walled Struct. 45 (2007) 339-351.

https://doi.org/10.1016/j.tws.2007.02.007

43. H. W. Zhang, Z. Zhang, and J. T. Chen, 3D modeling of material flow in friction stir welding under different process parameters, J. Mater. Process Technol. 183 (2007) 62-70.

https://doi.org/10.1016/j.jmatprotec.2006.09.027

44. A. Bastier, M. H. Maitournam, F. Roger, and V. K. Dang, Modelling of the residual state of friction stir welded plates, J. Mater. Process Technol. 200 (2008) 25-37.

https://doi.org/10.1016/j.jmatprotec.2007.10.083

45. H. B. Schmidt and J. H. Hattel, Thermal modelling of friction stir welding, Scr. Mater. 58 (2008) 332-337. https://doi.org/10.1016/j.scriptamat.2007.10.008

46. X. Qin and P. Michaleris, Themo-elasto-viscoplastic modelling of friction stir welding, Sci. Technol. Weld. Join. 14 (2009) 640-649.

https://doi.org/10.1179/136217109X12464549883457

47. M. Assidi, L. Fourment, S. Guerdoux, and T. Nelson, Friction model for friction stir welding process simulation: Calibrations from welding experiments, Int. J. Mach. Tools Manuf. 50 (2010) 143-155. https://doi.org/10.1016/j.ijmachtools.2009.11.008

48. P. Prasanna, B. S. Rao, and G. K. M. Rao, Finite element modeling for maximum temperature in friction stir welding and its validation, Int. J. Adv. Manuf. Technol. 51 (2010) 925-933.

https://doi.org/10.1007/s00170-010-2693-4

49. D. G. Richards P. B. Prangnell, P. J. Withers, S. W. Willams, T. Nagy, and S. Morgan, Efficacy of active cooling for controlling residual stresses in friction stir welds, Sci. Technol. Weld. Join. 15 (2010) 156-165. https://doi.org/10.1179/136217109X12590746472490

50. L. Wang, C. M. Davies, R. C. Wimpory, L. Y. Xie, and K. M. Nikbin, Measurement and simulation of temperature and residual stress distributions from friction stir welding AA2024 Al alloy, Mater. High. Temp. 27 (2010) $167-178$. https://doi.org/10.3184/096034010X12813743510192

51. D. Jacquin, B. D. Meester, A. Simar A, D. Delosion, F. Montheillet, and C. Desrayaud, A simple Eulerian thermomechanical modeling of friction stir welding, $J$. Mater. Process Technol. 211 (2011) 57-65. https://doi.org/10.1016/j.jmatprotec.2010.08.016

52. M. Riahi and H. Nazari, Analysis of transient temperature and residual thermal stresses in friction stir welding of aluminum alloy 6061-T6 via numerical simulation, Int. J. Adv. Manuf. Technol. 55 (2011)143-152. https://doi.org/10.1007/s00170-010-3038-z

53. A. H. Jamshidi, S. Serajzadeh, and A. H. Kokabi Experimental and theoretical evaluations of thermal histories and residual stresses in dissimilar friction stir welding of AA5086-AA6061, Int. J. Adv. Manuf. Technol. 61 (2012) 149-160. https://doi.org/10.1007/s00170-011-3713-8

54. F. Al-Badour, N. Merah, A. Shuaib, and A. Bazoune, Coupled Eulerian Lagrangian finite element modeling of friction stir welding processes, J. Mater. Process Technol. 213 (2013) 1433-1439.

https://doi.org/10.1016/j.jmatprotec.2013.02.014

55. H. S. Mun and S. I. Seo, Welding strain analysis of friction stir-welded aluminum alloy structures using inherent strain-based equivalent loads, J. Mech. Sci. Technol. 27 (2013) 2775-2782. https://doi.org/10.1007/s12206-013-0724-4

56. M. R. Sonne, C. C. Tutum, J. H. Hattel, A. Simar, B. D. Meester, The effect of hardening laws and thermal softening on modeling residual stresses in FSW of aluminum alloy 2024-T3, J. Mater. Process Technol. 213 (2013) 477-486. https://doi.org/10.1016/j.jmatprotec.2012.11.001

57. A. R. Darvazi and M. Iranmanesh, Prediction of asymmetric transient temperature and longitudinal residual stress in friction stir welding of $304 \mathrm{~L}$ stainless steel, Mater. Des. 55 (2014) 812-820.

https://doi.org/10.1016/j.matdes.2013.10.030

58. L. Shi, C. S. Wu, and H. J. Liu, Numerical analysis of heat generation and temperature field in reverse dual rotation friction stir welding, Int. J. Adv. Manuf. Technol. 74 (2014) 319-334. https://doi.org/10.1007/s00170-014-5967-4

59. C. Casavola, A. Cazzato, V. Moramarco, and C. Pappalettere, Influence of the clamps configuration on residual stresses field in friction stir welding process, $J$. Strain Anal. Eng. Des. 50 (2015) 232-242. https://doi.org/10.1177/0309324715573361

60. L. Shi, C. S. Wu, and X. C. Liu, Modeling the effects of ultrasonic vibration on friction stir welding, J. Mater. Process Technol. 222 (2015) 91-102. https://doi.org/10.1016/j.jmatprotec.2015.03.002

61. P. Asadi, M. K.B. Givi, and M. Akbari, Simulation of dynamic recrystallization process during friction stir welding of AZ91 magnesium alloy, Int. J. Adv. Manuf. Technol. 83 (2016) 301-311. https://doi.org/10.1007/s00170-015-7595-z

62. S. B. Aziz, M. W. Dewan, D. J. Huggett, M. A. Wahab, A. M. Okeil, and T. W. Liao, Impact of Friction Stir Welding (FSW) process parameters on thermal model- 
ing and heat generation of aluminum alloy joints, Acta. Metall. Sin. 29(2016) 869-883.

https://doi.org/10.1007/s40195-016-0466-2

63. M. Bachmann, J. Carstensen, L. Bergmann, J. F. D. Santos, C. S. Song and M. Rethmeier, Numerical simulation of thermally induced residual stresses in friction stir welding of aluminum alloy 2024-T3 at different welding speeds, Int. J. Adv. Manuf. Technol. 91 (2017) 1443-1452.

https://doi.org/10.1007/s00170-016-9793-8

64. N. Dialami, M. Cervera, M. Chiumenti, and C. A. D. Saracibar, Local-global strategy for the prediction of residual stresses in FSW processes, Int. J. Adv. Manuf. Technol. 88 (2017) 3099-3111. https://doi.org/10.1007/s00170-016-9016-3

65. Z. Hou, J. Sheikh-Ahmad, F. Jarrar, and F. Ozturk, Residual Stresses in Dissimilar Friction Stir Welding of AA2024 and AZ31: Experimental and Numerical Study, J. Manuf. Sci. Eng. Trans. 140 (2018) 1-10. https://doi.org/10.1115/1.4039074

66. H. Yu, B. Zheng, and X. Lai, A modeling study of welding stress induced by friction stir welding, $J$. Mater. Process Technol. 254 (2018) 213-220. https://doi.org/10.1016/j.jmatprotec.2017.11.022
67. S. Salimi, P. Bahemmat, and M. Haghpanahi, Study on residual stresses caused by underwater friction stir welding: FE modeling and ultrasonic measurement, Proceedings of the Institution of Mechnical Engineers, Part E: J. Process Mech. Eng. 233 (2019) 118-137. https://doi.org/10.1177/0954408917751963

68. X. X. Zhang, L. H. Wu, H. Andrä, W. M. Gan, M. Hofmann, D. Wang, D. R. Ni, B. L. Xiao, and Z. Y. Ma, Effects of welding speed on the multiscale residual stresses in friction stir welded metal matrix composites, J. Mater. Sci. Technol. 35 (2019) 824-832. https://doi.org/10.1016/j.jmst.2018.11.005

69. X. Xu, H. Yu, and Z. Lin, Study of residual stress variation with depth of friction stir welded aluminium plates with different thicknesses, Sci. Technol. Weld. Join. 25 (2020) 297-302.

https://doi.org/10.1080/13621718.2019.1693722

70. H. Yu, Y. Li, X. Xu, and B. Zheng, Out-of-plane distortion prediction of large thin-walled structures induced by friction stir welding, Sci. Technol. Weld. Join. 25 (2020) 45-55.

https://doi.org/10.1080/13621718.2019.1610603 